\title{
Study of the Health Effects of Red Beet J uice and Asorubine Food Dyes Used in Feeding and Watering of the Animals for Experience
}

\author{
MIHAELA CLAUDIA SPATARU ${ }^{1}$, CONSTANTIN SPATARU1*, CARMEN SOLCAN ${ }^{1}$, ANDREI CRISTIAN GRADINARU ${ }^{1}$, \\ RALUCA ELENA DONOSA², LUMINITA DIANA HRITCU ${ }^{1}$ \\ ${ }^{1}$ Ion Ionescu de la Brad University of Agricultural Sciences and Veterinary Medicine, Faculty of Veterinary Medicine, 8 Sadoveanu \\ Alley, 700490 lasi, Romania \\ ${ }^{2}$ Ion Ionescu de la Brad University of Agricultural Sciences and Veterinary Medicine, Faculty of Zootechny, 8 Sadoveanu Alley, \\ 700490, Iasi, Romania
}

\begin{abstract}
The paper aims to investigate the health effects of red beet juice and asorubine food dyes used in mice feeding and watering, considering the common use of these food colorants as additives in human food. The investigations related to this study were performed over a 3-month period, using 30 male mice which were divided into three batches 10 mice each. The red beet juice has given to nutrients and waters a better organoleptic quality so, the weight gain of mice was registered. The same, the increase in weight of mice receiving asorubine was higher. The anatomo- and histo-pathological examinations of mice that received red beet juice do not indicate a clear toxicity of this dye. However, red beet juice should not be consumed daily and in large quantities. On the other hand, injuries induced by asorubine in liver and kidneys may be characteristic for toxicity. So, the use and consumption of asorubine as a food additive should be undertaken with caution; although this compound is more stable and does not oxidize over time, if possible replace it with natural dyes.
\end{abstract}

Keywords: asorubine,food colorants, red beet, toxicity.

In Romania, the use of food colorants is based on Order No. 438/295 of 18J une 2002 for the approval of the Norms on Food Additives for use in foodstuffs for Human Consumption [1], whilein the EU the law in force is the Regulation (EC) No. 1333/2008 [2]. Red beetcolorant $\left(\mathrm{E}_{162}\right)$ is extracted from the roots of Beta vulgaris subsp. vulgaris plant, being a source of betaine $\left(\mathrm{C}_{24} \mathrm{H}_{27} \mathrm{~N}_{2} \mathrm{O}_{13}\right)$ [3], nitrats and potassium salts [4-5] (fig. 1).<smiles>C[N+](C)(C)CC(=O)[O-]</smiles>

Fig. 1. The Betaine chemical formula

At one hundred days of vegetation, the betanine content of beet roots was reported as about $99 \mathrm{mg} / 100 \mathrm{~mL}$ of sap, the extending of vegetation period from 100 to 140 days being accompanied by a decreasing of betanine content to $84 \mathrm{mg} / 100 \mathrm{~mL}$ of sap, an increasing of nitrate content from 2200 to $2660 \mathrm{KNO}_{3} / \mathrm{kg}$ fresh weight, and a decreasing of dry matter contents on average from 15.1 to $14.6 \%$ [6]. The beet root ingestion was reported to offer some benefits for several pathologies improving, especially for those associated with lower nitric oxide present in blood, oxidative stress and inflammation (hypertension, atherosclerosis, type 2 diabetes and dementia) [7]. Nevertheless, the consumption of boiled garden-fresh beets was associated with beeturia, reported only in some persons and characterized by purple-red color of urine and even of stools [8].

Asorubine $\left(\mathrm{E}_{122}\right)$, also known as Carmoisine $\left(\mathrm{C}_{20} \mathrm{H}_{12} \mathrm{~N}_{2} \mathrm{Na}_{2} \mathrm{O}_{7} \mathrm{~S}_{2}\right)$, is a red synthetic colorant soluble in water and stable in the food content (fig. 2) [9-10].

It is found in processed drinks such as Americano (Campari, Sweet Vermouth, Seltzer Cocktail), bitter soda, bitter vino [10]. If consumed at the level of $400 \mathrm{mg} / \mathrm{kg} / \mathrm{day}$ it is considered non-carcinogenic and does not show any

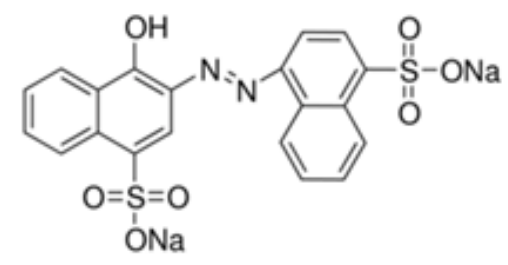

Fig. 2. The Asorubine chemical formula

adverse effect [11] although Karatepe et al. in 2017 [12] reported that its use even at low doses alter biochemical markers in vital organs such as the liver and kidneys. In this context, the aim of this study is to investigate the health effects of red beet juice and asorubine based food dyes used in mice feeding and watering.

\section{Experimental part}

Materials and methods

The investigations related to this study were performed over a 3-month period, using 30 male mice which were divided into three batches of 10 mice each. To achieve the proposed objectives, two food colorants were used, a natural one - fresh beet juice obtained by squeezing row red beets, and a synthetic one - asorubine, purchased from the market. These were gradually introduced in food and drinking water, considering the followings: on the first day of the experiment, $10 \mathrm{~mL}$ of red beet juice with $40 \mathrm{~mL}$ of drinking water were used for the first experimental batch $\left(B_{1}\right)$, and a mixture of dye and water was used to soften the bread; $5 \mathrm{~mL}$ of asorubine dissolved in $45 \mathrm{~mL}$ of drinking water were used for the second experimental batch $\left(B_{2}\right)$, a mixture of dye and water being also used to soften the bread as for the first group; the third batch of mice $\left(B_{3}\right)$ was considered for control, being fed and watered without added dyes. The added dye quantities were increased at every 4-5 days by $5 \mathrm{~mL}$ until the dye concentration in drinking water was $90 \%$. During the entire period of the experiment, three examinations were performed. Each animal was weighed and its blood glucose was measured

* email: cspatarufmv@yahoo.com 


\begin{tabular}{|c|c|c|c|c|c|}
\hline Batches & \begin{tabular}{|c|}
$\begin{array}{l}\text { Weight on the first day } \\
\text { of the experiment }(\mathrm{n}= \\
3) \\
\bar{X}(g)\end{array}$ \\
\end{tabular} & $\begin{array}{c}\text { Weight on the } 24^{\text {th }} \text { day } \\
\text { of the experiment }(\mathrm{n}= \\
3) \\
\bar{X}(g) \\
\end{array}$ & $\begin{array}{c}\text { Weight on the } 48^{\text {th }} \text { day } \\
\text { of the experiment }(\mathrm{n}= \\
3) \\
\bar{X}(g)\end{array}$ & \begin{tabular}{|} 
Weight on the $86^{\mathrm{at}}$ day \\
of the experiment $(\mathrm{n}=$ \\
$3)$ \\
$\bar{X}(g)$
\end{tabular} & \multirow{10}{*}{$\begin{array}{c}\text { Table } 1 \\
\text { THE BODY WEIGHT VARIATION } \\
\text { OF INDIVIDUALS INCLUDED IN } \\
\text { EXPERIMENTAL AND CONTROL } \\
\text { BATCHES DURING THE ENTIRE } \\
\text { EXPERIMENT }\end{array}$} \\
\hline \multirow{3}{*}{$\mathbf{B}_{1}$} & 29.00 & 31.33 & 33.66 & 33.66 & \\
\hline & 28.5 & 31.02 & 32.5 & 33.55 & \\
\hline & 29.5 & 32.25 & 33.50 & 34.25 & \\
\hline \multirow{3}{*}{$\mathbf{B}_{2}$} & 31.00 & 33.00 & 34.00 & 35.33 & \\
\hline & 32.3 & 33.5 & 34,33 & 35.66 & \\
\hline & 29.5 & 32.6 & 33.5 & 33,8 & \\
\hline \multirow{3}{*}{$\mathbf{B}_{3}$} & 29.00 & 31.33 & 31.66 & 31.66 & \\
\hline & 29.50 & 31.50 & 32.50 & 32.66 & \\
\hline & 29.55 & 31.50 & 33.00 & 33.15 & \\
\hline
\end{tabular}

using the glucose meter. Blood samples required for hematological investigations (red blood cell count - RBC, mean corpuscular volume - MCV, mean corpuscular hemoglobin - $\mathrm{MCH}$, mean corpuscular hemoglobin concentration - $M C H C$, hematocrit - $H C T$, hemoglobin concentration - $H b$, leukocyte series) were collected by intracardiac puncture of three mice per batch in the first two months of the experiment, and of four mice per batch in the last month of the experiment. The mice were euthanized in accordance with the European Commission (2010) [13] and Romanian Parliament (2014) [10] regulations, the organs samples were collected recording to the law.

\section{Results and discussions}

The body weight variation of individuals included in the experimental and control batches and expressed as arithmetic means at the first day of experiment, on the $24^{\text {th }}$ day, $48^{\text {th }}$ day and $86^{\text {th }}$ day of the experiment is shown in table 1.

So, during the period of three months, $B$ recorded a weight gain until the $48^{\text {th }}$ day, after that their weight remaining constant until the final. This weight gained is due to the introduction of red beetjuice in food and drinking water which, from our observations and also reported by Joris and Mensink [14], induces an increase in appetite.
The mice consumed the aqueous solution and granulated feed with more pleasure, faster and more often, in comparison, the mice of the control batch had had a moderate weight. $B_{2}$ recorded a continuous increase in weight during the three months of experiment compared to mice of $B$ and those of control. In addition a change in the individual behavior was observed, the investigated mice being more active and aggressive in their competition for food consumption. The blood samples were collected and analyzed for hematological parameters, the results obtained being presented in table 2 .

According to Fukuda et al. [15] the variations in hematological parameters may be explained in the following contexts: in the case of $B_{1}$, the decrease in the number of erythrocytes in association with the slightly decrease, but maintaining in normal range, in hemoglobin and hematocrit are related to the growing in weight. However, the decrease in hematocrit may also be due to an iron absorption disorder. By the end of the experiment, hematocrit and hemoglobin values recovered and anemia disappeared. We could say that in fact the anemia recorded in $B_{1}$ was a reaction to the sudden and excessive consumption of beet juice. In the case of the mice of $B_{2^{\prime}}$ the recorded hematological values are much lower than those of $B_{1}$ which benefited from the addition of red beet juice. A significant decrease in the number of red blood cells associated with decreased hemoglobin and

Table 2

MEAN VALUES OF THE INVESTIGATED HEMATOLOGICAL PARAMETERS (RBC, MCV, MCH, MCHC, HCT, HB), LEUKOCYTES AND GLYCEMIA

\begin{tabular}{|c|c|c|c|c|c|c|c|c|c|}
\hline \multirow{2}{*}{ 坣 } & \multirow{2}{*}{ Date of evaluation } & \multicolumn{6}{|c|}{$\begin{array}{l}\text { Mean (media) values of the investigated } \\
\text { hematological parameters } \\
\text { (RBC, MCV, MCH, MCHC, HCT, Hb) }\end{array}$} & \multicolumn{2}{|c|}{$\begin{array}{l}\text { Mean(media) } \\
\text { values of } \\
\text { leukocytes and } \\
\text { glycemia }\end{array}$} \\
\hline & & 놀 & 已̋ & త్రુ & 넉: & 与ั워 & 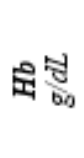 & 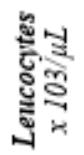 & 홇 \\
\hline \multirow{3}{*}{$\mathbf{B}_{1}$} & On the $24^{\text {th }}$ day of the experiment & 7.01 & 43.80 & 14.10 & 32.30 & 31.00 & 10.00 & 2.75 & 327 \\
\hline & On the $48^{\text {th }}$ day of the experiment & 5.49 & 38.30 & 13.10 & 34.30 & 21.00 & 10.20 & 2.80 & 250 \\
\hline & $\begin{array}{l}\text { On the } 86^{\text {th }} \text { day of the } \\
\text { experiment }\end{array}$ & 5.46 & 43.90 & 14.20 & 32.40 & 32.00 & 12.00 & 5.95 & 200 \\
\hline \multirow{3}{*}{$\mathbf{B}_{2}$} & On the $24^{\text {th }}$ day of the experiment & 3.69 & 40.7 & 14.10 & 34.73 & 15.00 & 5.20 & 3.10 & 382 \\
\hline & On the $48^{\text {th }}$ day of the experiment & 6.44 & 43.50 & 15.50 & 35.70 & 28.00 & 10.00 & 4.20 & 400 \\
\hline & $\begin{array}{l}\text { On the } 86^{\text {th }} \text { day of the } \\
\text { experiment }\end{array}$ & 6.86 & 45.20 & 14.90 & 32.90 & 31.00 & 10.20 & 4.30 & 436 \\
\hline $\mathbf{B}_{3}$ & On the $24^{\text {th }}$ day of the experiment & 7.24 & 42.80 & 16.60 & 38.70 & 37.00 & 12.00 & 6.55 & 122.50 \\
\hline
\end{tabular}


hematocrit was recorded in the $24^{\text {th }}$ day of the experiment. At $B$ mice, the mean values of leukocytes showed a decrease compared to the control batch of mice [16]. In $B_{2}$, it was recorded a decreasing of leukocytes number at the first and the third examination, and an increase in WBC at the second date of evaluation. However, this increasing falls in the normal range of this indicator. The mean values for blood glucose in the mice of the two experimental batches exceed the mean value of the control batch and even the maximum limit between 100-200 mg/dL [17]. In the case of $B_{1}$, the mean values in the three examinations follow a descending trend, but in the case of the mice $B_{2}$, the mean values are increasing, being an indicator of $a^{\prime}$ pancreatic and hepatic disorder. As a result of the anatomopathological investigations performed in a comparative manner between the mice of $B$ and those of the control batch on the $24^{\text {th }}$ day of the experiment, the following aspects were observed and showed in figure $3 a$ and $b$ : the mice of $B$ had an increased stomach volume, occupying a relatively large area in the abdominal cavity, pushing the intestines (fig. 3).

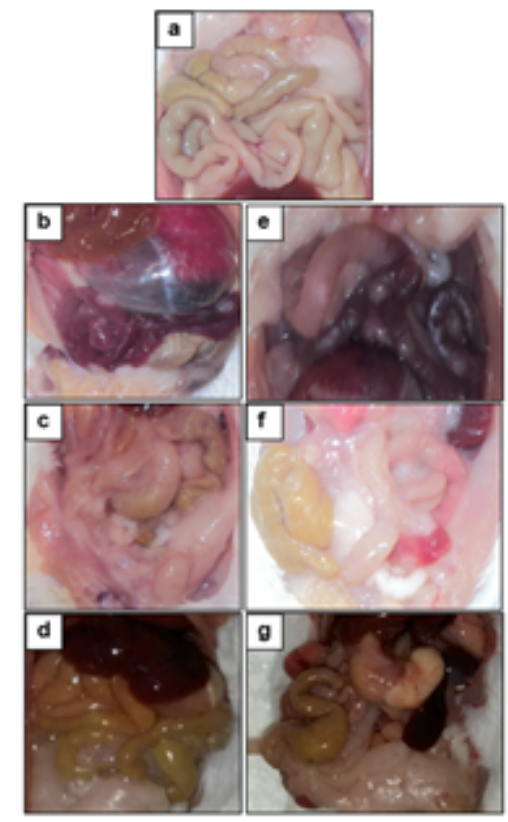

Fig. 3. The aspect of the gastro-intestinal mass at the experimental mice: $a$. $B_{3^{\prime}}$ control batch; $b . B_{1}$, on the $24^{\text {th }}$ day of the experiment; c. $B_{1}$, on the $48^{\text {th }}$ day of the experiment; $d$. $B_{1}$, on the $86^{\text {th }}$ day of the experiment; e. $B_{2}$, on the $24^{\text {th }}$ day of the experiment; f. $B_{2}$, on the $48^{\text {th }}$ day of the experiment; $g . B_{2}$, on the $86^{\text {th }}$ day of the experiment

The stomach was dilated by the food content, it had very thin and transparent walls in the aglandular area, the margo plicata was barely visible both in the exterior and in the examination of the gastric cavity, and the glandular, gastric and pyloric mucosa stretched out without the characteristic pleats. The color of the intestines was darkred and the liver did not show any major changes, only a slightly increased volume, of red color and glossy appearance with unchanged consistency due to the red beet components that play a role in detoxifying this organ. In the next examinations ( 48 days and 86 days, respectively), the consistency of the liver taken from the mice of $B_{1}$ was friable because of the hyperemia produced by nitrate supplementation $[4,18,19]$. The stomach was half the size of a normal stomach observed in the control batch of mice, with little or no gastric content, and the walls were thickened in both the glandular and aglandular part at $48^{\text {th }}$ and $86^{\text {th }}$ days (fig. $3 c$ and d). The differences found in mice of $B_{1}$ compared to those of the control batch both in the anatomo-pathological exam of the liver and the stomach showed that the changes occurred mainly after a long period of consumption or after an excessive consumption of red beet juice which, in the first phase is beneficial for the body, but extended over long periods of time maybe leads to the accumulation of toxic substances in the body with altering the function of some organs. At the intestinal level of the mice included in $B_{1}$, it was observed that at the first examination on the $24^{\text {th }}$ day of the experiment the intestines were loaded with food and had intense red color because of the red beet juice pigmentation of tissues and organs as well as due to the intensification of local circulation that facilitated the absorption. At the necropsy exam performed on the $48^{\text {th }}$ and $86^{\text {th }}$ days of the experiment, the intestines were of normal size but they had a reduced amount of intestinal content. In the case of the mice of $B_{2}$, the morpho-pathological examination (fig. $3 e-3 g$ ) on the $24^{\text {th }}$ day of the experiment revealed a faint stomach that occupied much of the abdominal cavity, with thinned wall of red color while the color of the liver was brick-ish in color. The intestines were of cherry color, being found pushed by the stomach in the lower abdominal part to the pelvic cavity. The post-mortem examination on the $24^{\text {th }}$ day of the experiment of the liver taken from the mice included in $\mathrm{B}_{2}$ revealed its pale color, its slightly increased volume, with a friable consistency.

Compared to the control group, the spleen did not show any major changes at this moment. If there were considered individuals of the same experimental batch but on the $48^{\text {th }}$ and on the $86^{\text {th }}$ days of the experiment, their liver had a dark-red color, with glossy appearance and without any other visible alterations. The stomach was very low in volume, with an atrophied look, pale in color and no content. At the morpho-pathological exam on day 86 of the experiment, the spleen was enlarged in volume, lightly colored, indicating a hyperplasic spleen. If at the $24^{\text {th }}$ day of the experiment the intestines were loaded with food and were stained red, the subsequent examinations on days 48 and 86 of the experiment revealed a deviation of their color to yellow, the consumption of asorubine printing the red color of the digestive tract.

From the histological point of view, the liver of the first experimental batch of mice (fig. $4 b, c$ and d) investigated after 24 days of the experiment showed obvious but lowintensity changes in areas of acidophilic hepatocytes, bile duct hyperplasia and small oval cell groups involved in differentiation for regeneration. There was observed the dilatation of the venule from the protobiliar space, which was filled with figural elements. The nuclei of hepatocytes were enlarged, many hepatocytes being binucleated and a small number of these having apoptotic cell characteristics. However, although the liver of $B$, presented various histological differences from the control batch of mice, these cannot be considered toxic effects of red beet juice adding. Red beet juice is known to have antioxidant, anti-inflammatory and anti-tumoral effects [20]. The liver histo-pathological lesions of $B_{2}$ ( fig. $4 e, f$ and $g$ ) at 24 days of experiment consisted of congestion and a discrete perivascular edema, with apoptotic hepatocytes observed.

Diffuse and clogged acidophilic hepatocytes with granular distrophia characteristics, and perivascular edema were also remarked through the dilatation of the Disse spaces. Asorubin-induced lesions as a result of its addition in food and drinking water of mice of $B_{2}$ and represented by congestion, stasis and edema, along with hepatocyte apoptosis, are characteristics of hepatotoxicity. On the $24^{\text {th }}$ day of the experiment, slight congestive changes occured [21] in the kidneys of B1 placed between cortical part and medulla (fig. 5b). Can be noticed that the blood cells are 


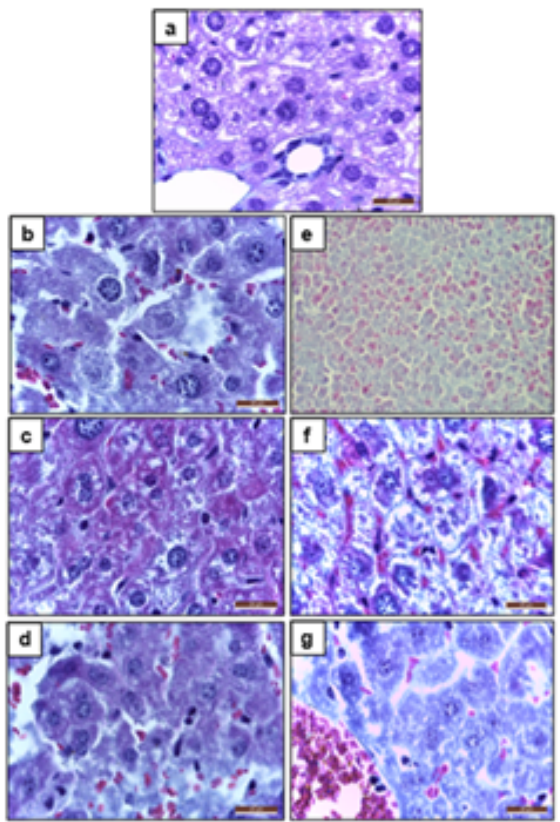

Fig. 4. The histo-pathological aspect of the experimental mice liver:a. $B_{3^{\prime}}$ control batch, HEA $90 x ; b . B_{1}$, on the $24^{\text {th }}$ day of the experiment, HEA $90 x ; C . B_{1}$, on the $48^{\text {th }}$ day of the experiment, HEA $90 x ; d . B_{1}$, on the $86^{\text {th }}$ day of the experiment, HEA $90 x ;$;. $B_{2}$, on the $24^{\text {th }}$ day of the experiment, HEA $20 x$; $f$. $B_{2^{\prime}}$ on the $48^{\text {th }}$ day of the experiment, HEA $90 x ; g . B_{2}$, on the $86^{\text {th }}$ day of the experiment, HEA 90x.

unusual pigmented, such as in liver, aspect which disappears on the last examination and which is related, as Tesoriere etal. [22] reported, to the elimination of betaine through urine (beeturia).

At 48 days of experiment, acidophilic and apoptotic cells were observed but in small number (fig. 5c). At the last 86day of examination, the previously described lesions persisted, adding to them breakings of the intercellular epithelial junctions of urine tubes followed by their

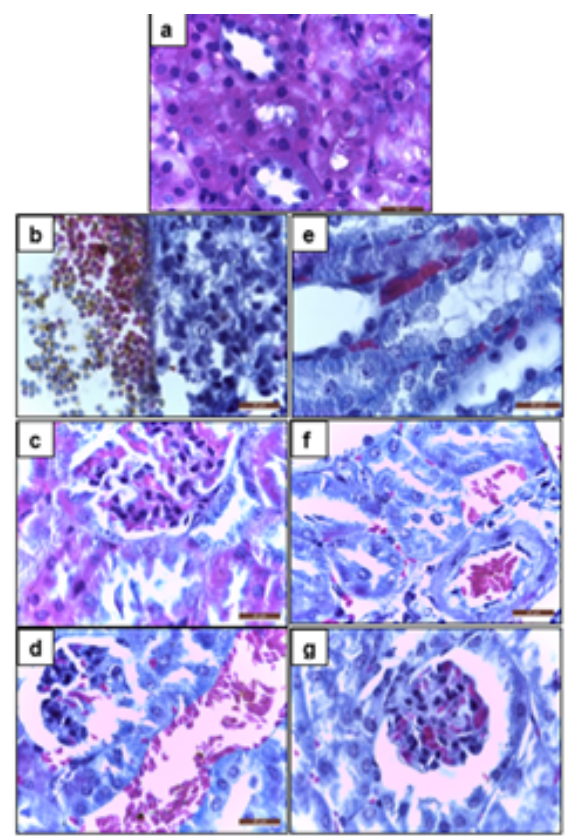

Fig. 5. The experimental mice kidneys histo-pathological aspect: a. $B_{3^{\prime}}$ control batch, HEA $90 x ;$ b. $B_{1}$, on the $24^{\text {th }}$ day of the experiment, HEA $90 x ; C . B_{1}$, on the $48^{\text {th }}$ day of the experiment, HEA $90 x ; d . B_{1}$, on the $86^{\text {th }}$ day of the experiment, HEA $90 x ; e . B_{2}$, on the 24th day of the experiment, HEA $20 x ; f$. $B_{2}$, on the $48^{\text {th }}$ day of the experiment, HEA $90 x ; g . B_{2}$ on the $86^{\text {th }}$ day of the experiment, HEA 90X detachment, probably caused by the accumulation of oxalat salts in urine (fig. $5 \mathrm{~d}$ ). The raw juice of red beet was reported to contain about $3.68 \%$ oxalate which can develop calcium-oxalate kidney stones or gallstones [23]. The kidney lesions of the $B_{2}$ are somewhatcomparable to those of the liver, which are translated by congestion, stasis and perivascular edema that cause nephrotoxicity (fig. $5 e, f$ and $\mathrm{g}$ ).

Soltan S. and Manal M. [24] also reported congestion of the renal veins, the presence of proteins in the lumen, and perivascular leukocyte infiltrationas a result of asorubine consumption.

\section{Conclusions}

Mice given the natural dye of red beet juice recorded constant increases in their weight, between 4 and $6 \mathrm{~g}$ throughout the experiment. Their hematological analyzes showed a decrease in erythrocyte count to $5.46 \times 10^{\%} / \mathrm{\mu L}$, associated with decreased hemoglobin and hematocrit. Following the necropsy exam, the mice exposed to 86 days of experiment showed an increase in liver volume. Histologically, hepatic changes were represented by areas of acidophilic hepatocytes, bile duct dilatation and deep hyperemia. In the kidney of these mice, slight congestive changes occurred at the cortical and medulla limit, and apoptotic cells in small numbers were observed after 48 days of experiment.Regarding mice that received asorubine addition, hematological tests applied revealed anemia. Histological lesions of the liver of the mice which received asorubine addition consisted of congestion and discrete perivascular edema and dilatation of Disse spaces. The same lesions were found into the kidney of these mice.

\section{References}

1.*** Romanian Parliament 2002. Order 438/295 of the Minister of Health and Family, and of the Minister of Agriculture, Food and Forestry for the approval of the norms on food additives for use in foodstuffs for human consumption, Official J ournal, Part I, 722 bis.

2. *** European Commission 2008. Regulation (EC) 1333/2008 of the European Parliament and of the Council of 16 December 2008 on food additives, Off J Eur Union L354, p.16.

3. ZHAO, G., HE, F., WU, C., LI, P., LI, N., DENG, J., ZHU, G., REN, W., PENG, Y., Front Immunol., 9, 2018, p. 1070, doi: 10.3389/ fimmu.2018.01070

4. CASEY, D.P., MADERY, B.D., CURRY, T.B., EISENACH, J.H., WILKINS, B.W., J OYNER, M.J.,J Physiol., 588, No. Pt 2, 2010, p. 373, doi: 10.1113/ jphysiol.2009.180489.

5. CHANDRAN, J., NISHA, P., SINGHAL, R.S., PANDIT, A.B., J. Food Sci. Technol., 51, No. 10, 2014, p. 2678, doi: 10.1007/s13197-012-0741-9

6. MICHALIK, B., GRZEBELUS, D., Acta Hortic., 379, 1995, p. 205, https://doi.org/10.17660/ActaHortic.1995.379.25

7. CLIFFORD, T., HOWATSON, G., WEST, D.J ., STEVENSON, E.J ., Nutrients,7, No. 4, 2015, p. 2801, doi: 10.3390/nu7042801

8. REIMANN, H.A., JAMA, 241, No. 22, 1979, p. 2380, doi:10.1001/ jama.1979.03290480014009

9. *** Evaluation of certain food additives and contaminants, 27th Report of J oin FAO/WHO Expert Commitee on Food Additives, World Health Organization, World Geneva 1983, Series No 18, 1983, p. 19, ISBN 9241206969.

10. *** Romanian Parliament2014. Law 43/2014 of Romanian Parliament on the protection of animals used for scientific purposes, Official J ournal, Part I, p. 326:2-4.

11. SAEED, S.M.G., ABDULLAH, S.U., SAYEED, S.A., ALI, R., Czech. J. Food. Sci., 28, No. 6, 2010, p. 506.

12. KARATEPE, A., AKALIN, C., SOYLAK, M., Turk. J. Chem., 41, 2017, p. 256. doi:10.3906/kim-1606-45. 
13.*** European Commission 2010. Directive 2010/63/EU of the European Parliament and of the Council of 22 September 2010 on the protection of animals used for scientific purposes. Off J Eur Union, L276, p. 33.

14. JORIS, P.J., MENSINK, R.P., Atherosclerosis, 231, 2013, p. 78, DOI: 10.1016/j.atherosclerosis.2013.09.001

15. FUKUDA, T., ASOU, E., NOGI, K., GOTO, K., J, Vet. Med. Sci., 79, No. 10, 2017, p. 1707, DOI: 10.1292/jvms.17-0387

16. SIMONDS, J.P., Anat. Rec., 30, No. 2, 1925, p. 99.

17. SUN, C., LI, X., CANET, M.J., GUAN, Y., FAN, Y., ZHOU, Y., Int. J. Clin. Exp. Med., 9, No. 2, 2016, p. 4186, www.ijcem.com /ISSN:19405901/IJ CEM0016658.

18. MASSCHELEIN, E., VAN THIENEN, R., WANG, X., VAN SCHEPDAEL, A., THOMIS, M.; HESPEL, P., J. Appl. Physiol., 113, 2012, p. 736, DOI: 10.1152/japplphysiol.01253.2011
19. FERGUSON, S.K., HIRAI, D.M., COPP, S.W., HOLDSW ORTH, C.T., ALLEN, J.D., JONES, A.M., MUSCH, T.I., POOLE, D.C., J Physiol., 591 No2,2013, p. 547, doi: 10.1113/jphysiol.2012.243121.

20. GEORGIEV., V.G.; BLEY, T., PAVLOV, A.I., Red Beet Biotechnology, 2012, 2012, p. 251, link.springer.com/content/pdf/10.1007\%2F978-14614-3458-0.pdf.

21. NETZEL, M., STINTZING, F.C., QUASS, D., STRASS, G., CARLE, R., BITSCH, R., FRANK, T.; Food. Res. Int., 38, 2005, p. 1051. doi:10.1016/ j.foodres.2005.03.010.

22. TESORIERE, L., GENTILE, C., ANGILERI, F.;, ATTANZIO, A., TUTONE, M., ALLEGRA, M., LIVREA, M.A., Eur. J. Nutr., 52, 2013, p.1077. DOI: 10.1007/s00394-012-0414-5.

23. ENKHTUYA, N., BAATAR, D., ODONTUYA, L., Proceedings of the Mongolian Academy of Sciences, 52, No. 04, 2012, p. 55.

24. SOLTAN, S., MANAL, M., FNS, 3, No. 7, 2012, p. 897.doi:10.4236/ fns.2012.37119

Manuscript received: 7.12 .2018 